\title{
Cultura Cultura
}

\section{O martírio de Inácio de Azevedo e dos seus trinta e nove companheiros (1570) na hagiografia da Companhia de Jesus entre os séculos XVI e XIX}

The 1570 martyrdom of Blessed Ignatius de Azevedo and his thirty nine companions in the hagiography of the Society of Jesus between the $16^{\text {th }}$ and $19^{\text {th }}$ centuries

\section{Maria Cristina Osswald}

\section{(2) OpenEdition}

\section{Edição electrónica}

URL: http://journals.openedition.org/cultura/354

DOI: $10.4000 /$ cultura.354

ISSN: 2183-2021

\section{Editora}

Centro de História da Cultura

\section{Edição impressa}

Data de publição: 1 Junho 2010

Paginação: 163-186

ISSN: 0870-4546

\section{Refêrencia eletrónica}

Maria Cristina Osswald, « O martírio de Inácio de Azevedo e dos seus trinta e nove companheiros (1570) na hagiografia da Companhia de Jesus entre os séculos XVI e XIX », Cultura [Online], Vol. 27 | 2010, posto online no dia 08 agosto 2013, consultado a 01 maio 2019. URL : http:// journals.openedition.org/cultura/354; DOI : 10.4000/cultura.354 


\title{
O martírio de Inácio de Azevedo \\ e dos seus trinta e nove companheiros (1570) na hagiografia da Companhia de Jesus entre os séculos XVI e XIX
}

\author{
Maria Cristina Osswald*
}

"Los que muertos veneramos por su Dios. si non los seguimos nos, que ganamos?" (José de Anchieta, Los que muertos veneramos - cantiga)

\section{Aspectos gerais do significado do martírio de Inácio de Azevedo e dos seus trinta e nove companheiros para a Companhia de Jesus}

No dia 15 de Julho de 1570 o jesuíta português Inácio de Azevedo, trinta e oito companheiros (trinta portugueses e oito espanhóis) e ainda o candidato à Companhia Juan de San Juan, que era sobrinho do capitão da nau, foram "distinguidos com a Coroa do Martírio" nos mares das Ilhas Canárias às mãos de corsários comandados pelo calvinista francês Jacques Soria, quando se dirigiam para a Missão do Brasil. No dia seguinte foi martirizado o irmão jesuíta Simão Costa.

Este martírio constituiu um episódio de grande actualidade devocional e iconográfica em uma época caracterizada por inúmeros episódios de martírio cristão, em especial de jesuítas, dentro e fora da Europa. Reflectindo tal facto, a cornija de // Gesù, então igreja mãe da Companhia de Jesus, durante as celebrações da dupla canonização de Inácio de Loiola e Francisco Xavier, os dois primeiros santos jesuítas, em 1622, foi decorada com um friso de imagens representando os cento e um jesuítas mortos pela fé até à data ${ }^{1}$. Todavia, este número conheceu um significativo e rápido aumento. A principal obra em honra dos mártires jesuítas pelo flamengo Mathias Tanner de 1675 menciona nada menos que trezentos e quatro mártires jesuítas².

* Pós-doutoranda na Universidade do Minho, UNED (Madrid) e UNICAMP (Brasil).

1 Azzolini SI, Ilario M., Le immagini dei martiri della Compagnia di Gesù nell'addobbo del tempio farnesiano per la canonizzazione del 1622, in Canonizzazione dei Santi Ignazio di Loyola Fondatore della Compagnia di Gesù e Francesco Saverio Apostolo dell'Oriente, Comitato Romano Ispano per le Centenarie Onoranze (ed.), Roma, Grafia, 1922, pp. 94-99 e Osswald, Maria Cristina, Iconografia das Cerimónias de Canonização no Contexto Português, in Brotéria 163 (2006), p. 338.

2 Tanner, Mathias, Societas lesu usque ad Sanguinis et vitae profusionem militans in Europa, América, Ásia, et Africa, Praga, Typ. Universitatis Carolo-Ferdinandeae, 1675. 


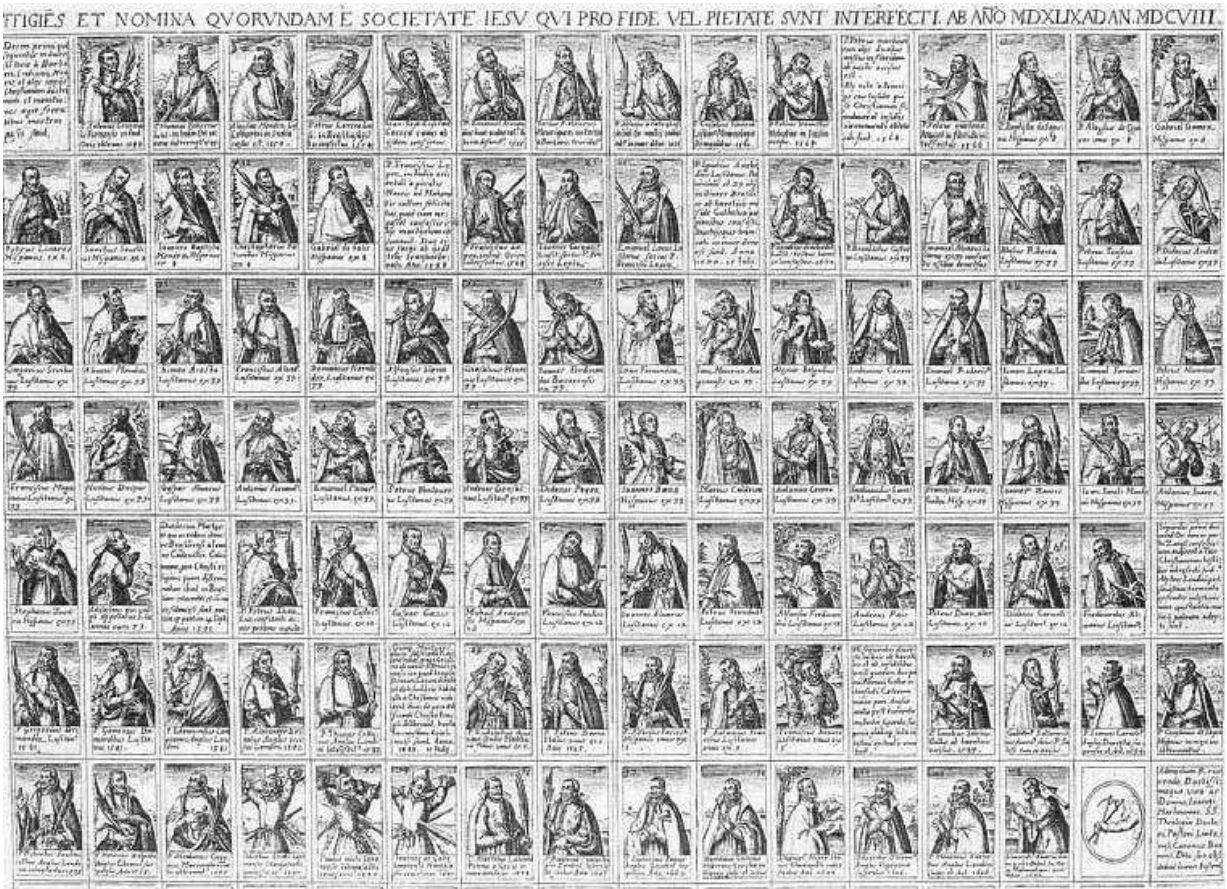

1. Johann Bussemacher, Galeria de mártires da Companhia, 1609, col. privada.

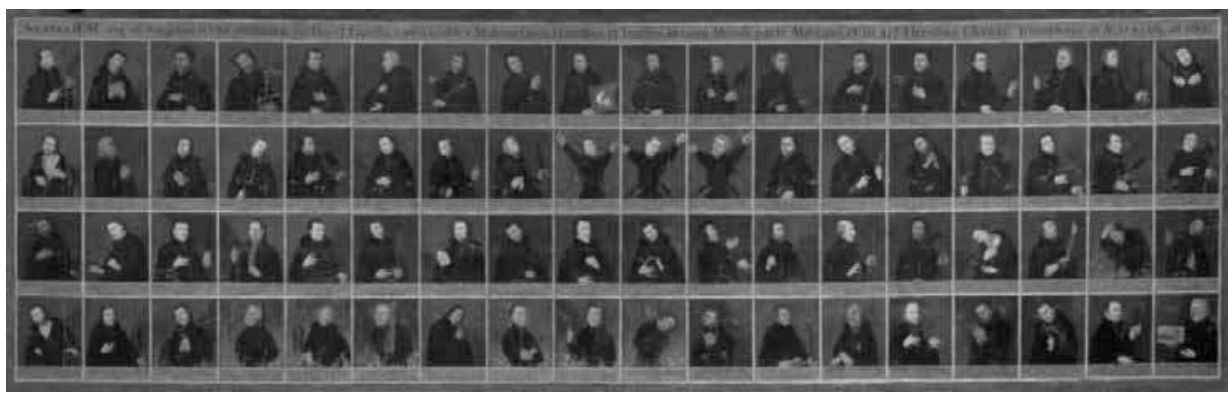

2. Autor anónimo (alemão?), Galeria de mártires da Companhia, óleo, 1695, Museu Diocesano de Paderborn (cortesia de Johannes Meier).

O tema do martírio assumiu um carácter especial para os jesuítas, que foram com os oratorianos os grandes fomentadores ou mecenas desta iconografia. Entre finais do século XVI e a segunda década do século XVII todas as casas da Companhia de Jesus em Roma 
foram decoradas com ciclos de pinturas a fresco representando episódios individuais ou colectivos de martírio. O Geral Claudio Acquaviva (1543-1605), uma das figuras mais marcantes da história da Velha Companhia, foi igualmente decisivo no fomento do culto dos mártires. Cláudio Acquaviva (1543-1605), cujo sobrinho Rodolfo chefiava o grupo de jesuítas mártires na vila de Salsete de Goa em 1583, tinha uma colecção de quadros de mártires e beatos jesuítas nos seus aposentos para a sua meditação individual.É ainda importante realçar o facto de que Claudio Acquaviva concebeu o programa iconográfico do noviciado romano de Sant'Andrea al Quirinale. É ainda provável que o Geral Acquaviva tenha encomendado outros ciclos pictóricos com cenas de martírio ${ }^{3}$.

(Figs. 1 e 2) Regressando ao episódio de martírio de 1570, atribuímos ao mesmo um alto valor simbólico, dado "reunir" os dois mundos ou contextos geográfico-culturais, nos quais aconteciam estes episódios: a Europa dilacerada pelas guerras de religião e as missões católicas fora da Europa ${ }^{4}$. Esta expedição foi simultaneamente a expedição com maior número de jesuítas partindo de Lisboa para as missões ultramarinas e o martírio colectivo mais numeroso em toda a Época Moderna. Por tal razão, as assim denominadas galerias de mártires jesuítas, que foram pintadas e impressas a partir da beatificação de Inácio de Loyola (1609), são constituídas sobretudo por retratos dos mártires de $1570^{5}$.

A partir do primeiro relato do martírio destes quarenta homens por Maurizio Serpe (1572), a hagiografia destaca o facto de Inácio de Azevedo ter sido a primeira pessoa, a quem foi concedida autorização papal para levar consigo uma cópia da imagem da Madonna di San Luca. Esta imagem, que se conserva na Basílica de Santa Maria Maior, era, ao tempo, considerada uma acheiropoieton, isto é, uma imagem com carácter divino e com capacidades taumatúrgicas. Pensava-se que a mesma imagem fosse um retrato de Nossa Senhora ao vivo pelo Apóstolo São Lucas ${ }^{6}$.

3 Bailey, Gauvin Alexander, Between Renaissance and Baroque, Jesuit Art in Rome, 1565-1610. Toronto/ Buffalo/London: University of Toronto Press, 2003, p. 13.

4 Hernández Palomo, José e Osswald, Maria Cristina, Aspectos del culto a Ignacio de Azevedo y sus treinta y nueve compañeros mártires en 1570, in Sevilla y América en la historia de la Compañía de Jesus, ed. por José Hernández Palomo e José del Rey Fajardo SJ, Roma-Sevilha, Institutum Historicum Societatis lesu e Escuela de Estudios Hispano-Americanos/Consejo Superior de Investigaciones Científicas (no prelo).

5 Estas galerias, que aparentemente foram exclusivas da Companhia de Jesus, mostram os jesuítas por ordem cronológica do seu martírio. Os jesuítas têm nas mãos uma palma. Trata-se do tradicional atributo do martírio e, em alguns casos, ainda outros instrumentos de martírio que, todavia, nem sempre correspondem aos instrumentos mencionados nas fontes documentais.

6 No relato de Paolo de Angelis descrevendo a construção e decoração da Capela Paulina (1606 a 1613), onde esta imagem devia ser guardada, defende-se que esta imagem tinha sido concluída por anjos. (De Angelis, Paolo, Basilicae S. Mariae Maioris de Vrbe a Liberio papa 1. vsque ad Paulum 5. Pont. Max. descriptio 


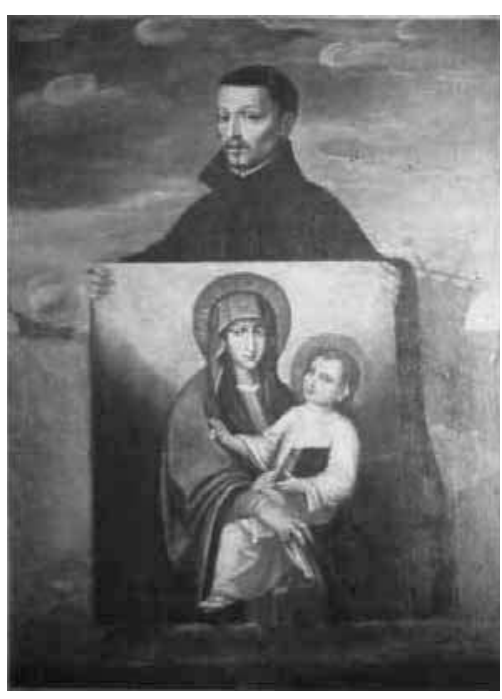

3. Pintor português, O Beato Inácio de Azevedo com a imagem da Madona di San Luca nas mãos, óleo, século XVIII, colecção particular.
(Fig. 3) Em especial, o protótipo iconográfico de Inácio de Azevedo com um retrato da Madonna de San Luca nas mãos, enquanto expirava às mãos dos corsários, fixou definitivamente na hagiografia e na iconografia a ligação entre este mártir e o culto tipicamente jesuíta da Madonna di San Luca. Na origem desta ligação encontra-se o facto de que se deve a Inácio de Azevedo a introdução deste culto em Portugal ${ }^{7}$. $O$ jesuíta mártir, que tinha sido encarregado pelo Geral Francisco de Borja (1510-1572) de levar uma cópia da Madona ditípicam San Luca para a Rainha de Portugal D.Catarina, mandou fazer reproduções desta mesma imagem, as quais colocou à veneração nos colégios jesuítas de Coimbra e Évora8 ${ }^{8}$.

Azevedo está ainda ligado de forma indirecta ao sucesso deste culto no Brasil. Até ao século XVIII acreditava-se que a imagem da Madonna di S. Luca na actual Catedral e antiga Igreja do Colégio Jesuíta de Salvador da Bahia era a mesma imagem que Azevedo teria nas mãos quando foi martirizado. Segundo alguns autores seiscentistas e setecentistas, esta imagem tinha ainda vestígios do sangue dos dedos de Inácio de Azevedo, pois os piratas tinham sido incapazes de a tirar das mãos do cadáver. Na versão mais difundida desta lenda, o corpo de Azevedo ficou a boiar segurando esta imagem até que o seu braço direito a depositou suavemente nas mãos dum homem católico, que seguia numa outra nau. Na ilha da Madeira, este homem teria entregue a imagem aos jesuítas que a fizeram chegar ao colégio da Bahia?

(Figs. 4 e 5) De igual modo, o significado especial deste episódio dentro da hagiografia está relacionado com a figura de Santa Teresa de Ávila, que foi uma das figuras mais relevantes da espiritualidade pós-tridentina. A visão contemporânea do martírio por parte de Teresa de Ávila, episódio que foi incluído nos processos da sua canonização, foi o pre-

et delineatio, Roma, typographia Bartholomaei Zannetti, 1621 e Ostrow, Stephen, Art and Spirituality in Counter-Reformation Rome, Cambridge, Cambridge University Press, 1996, pp. 122-123 e 118-151.)

7 Franco, António, Imagem da Virtude em o noviciado da Companhia de Jesus no Real Collegio de Jesus de Coimbra em Portugal,Évora, Officina da Universidade, 1719, vol. II, pp. 77-78.

8 Idem, ibidem, pp. 193-194.

9 Cabral, Antonio, Relación del martyrio de los quarenta martyres de la Compañia de Jesus: vida del venerable martyr P. Ignacio Acevedo, Madrid, Imprensa y Libraria de Manuel Fernandez, 1744, pp. 206-207. 


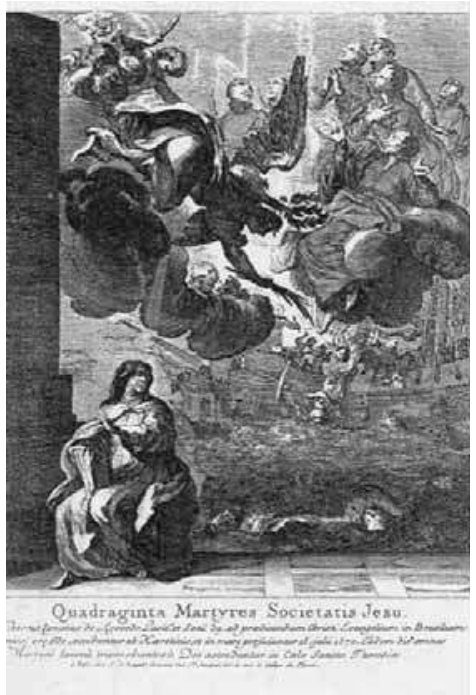

4. Giuseppe Baguasco, O Martírio de Inácio de Azevedo, óleo, 1855, Casa Professa da Companhia de Jesus, Roma (cortesia da Vice-Procuradoria dos mártires do Brasil).

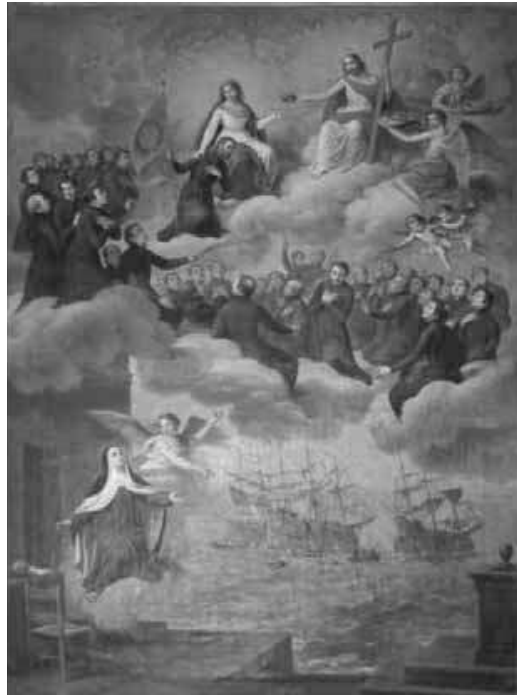

5. Gravura representando o Martírio de Inácio de Azevedo e a respectiva visão de Teresa de Ávila, in Hamy, Hamy SJ, Alfred, Gallerie illustrée de la Compagnie de Jesus, Paris, chez l'auteur, 1893, vol. I, s/p, s/nr. (cortesia do Archivum Historicum Societas lesu, Roma).

sumível milagre que esteve na origem da beatificação dos mártires jesuítas. Por tal razão, a iconografia oficial pós-beatificação estabeleceu a visão de Teresa de Ávila em conjunto com a glorificação dos quarenta mártires em 1570, como um dos mais representativos protótipos iconográficos destes mártires fixados durante a época da beatificação, como vemos em um quadro de Giuseppe Baguasco de 1855 e na respectiva gravura do Beato Inácio de Azevedo ilustrando a obra do P. Alfredo Hamy de $1893^{10}$.

Pensamos que este episódio assumiu simultaneamente um carácter político. Como observado por Zulmira Coelho dos Santos, os esforços da Província do Brasil para fomentar o culto do seu "apóstolo" Anchieta e os mártires de 1570 inserem-se numa estratégia, aliás sem grande êxito, de promoção da Missão do Brasil por alguns responsáveis jesuítas. O objectivo era ademais contrabalançar o peso da Missão do Oriente e da figura de Francisco Xavier ${ }^{11}$.

10 Hamy SJ, Alfred, Gallerie illustrée de la Compagnie de Jesus, Paris, chez l'auteur, 1893, vol. I, s/p, s/nr.

11 Coelho dos Santos, Zulmira, Em busca do paraíso perdido: a Chronica da Companhia de Jesu do Estado do Brasil de Simão de Vasconcellos S. J., in Quando os Frades faziam Hstória - De Marcos de Lisboa a Simão de Vasconcellos, Porto, Centro Interuniversitário de História da Espiritualidade, 2001, pp. 174- -175. 
Gostaríamos ainda de relacionar com esta política a muito provável participação directa nesta causa do P.António Vieira durante a sua estadia em Roma entre 1669 e 1673 e o facto de esta mesma causa ter sido financiada pela Província do Brasil'12.

\section{Características fundamentais e evolução do culto dos quarenta mártires}

Os processos de beatificação destes quarenta mártires começaram em 1628 em Coimbra, em conjunto com os processos de um segundo grupo de doze jesuítas igualmente martirizados nos mares das Canárias a caminho do Brasil no ano seguinte. Os processos foram depois limitados aos mártires de 1570, devido ao grande número de jesuítas martirizados $^{13}$.Em 1742 Bento XIV reconheceu o martírio dos quarenta mártires de 1570. A sua beatificação data de 11 de Maio de 1854, decorrendo os processos para a sua canonização ${ }^{14}$.

Este grupo de mártires ficou conhecido na hagiografia por mártires do Brasil, dado o destino da sua viagem. Todavia, nas Canárias estes mártires são chamados de mártires de Tazacorte, cidade onde celebraram a sua última missa em terra firme, antes de embarcarem pela última vez.

O culto destes quarenta homens começou pouco depois do próprio evento. A carta de Pedro Diaz de 17 de Agosto de 1570 (líder da segunda expedição de jesuítas mártires em 1571), que constitui o relato mais antigo deste martírio, foi traduzida para italiano e incluída na obra Nuovi Avisi publicada em Roma ainda em $1570^{15}$. Entre os mais importantes e antigos devotos dos quarenta mártires, encontrava-se o Geral Francisco de Borja, que tinha contactado em Roma com Inácio de Azevedo. Segundo a hagiografia, o Geral Borja tinha por hábito encomendar-se diariamente aos quarenta mártires.

12 Citamos uma das várias afirmações do P. António Vieira, que nos permitem acreditar num seu envolvimento directo com esta causa:"Fico tratando da canonização dos mártires, em que brevemente se tomarão a última resolução, depois da qual saberei o que há-de de ser de mim." (Carta do P. António Vieira a D. Rodrigo de Menezes, 23.2.1671, in Cartas do Padre António Vieira, coordenadas e anotadas por J.Lúcio de Azevedo, Lisboa, Imprensa Nacional-Casa da Moeda, 1970, vol. II, p. 327 e ver também Alden, Dauril, The making of an enterprise, the society of Jesus in Portugal, its empire, and beyond, Stanford, Stanford University Press, 1996, p. 641).

13 Tal dificuldade foi sentida pelo P. António Vieira: “Eu fico trabalhando na canonização dos mártires, que por muitos, e portugueses, têm encontrado grandes embaraços na emulação; contudo esperamos que antes da Páscoa nos dê Sua Santidade estas boas festas" (Carta do P. António Vieira SJ ao Marquês de Gouveia, 31.1.1671, in Cartas do P. António Vieira, ed. João Lúcio Azevedo, Lisboa, Imprensa Nacional, 1971, vol. II, p. 317).

14 Archivio della Postulazione [AdP], 20 Brasilien. Redingrationis Cultus Ven. Servorum Dei lgnatii de Azevedo et XXXIX. Sociorum Martyrium E. Soc. lesu. Summarium Super Dubio, 21 Set. 1742, F.F. A Cardinalis Guadagni Pro Prafectus e AdP. 20, Decretum Brasilien Redingrationis Culturs Ven. Servorum Dei Igntatii de Azevedo et XXXIX. Sociorum Martyrum et Societate Jesu, 1854.

15 Leite, Serafim, Novas Páginas da História do Brasil, São Paulo, Comp. Editora Nacional, 1965, p. 129. 
Em 1571 Pio V honrou os quarenta mártires ao referir o seu martírio voluntário (motu proprio) na breve Dum Indefese de 7 de Julho ${ }^{16}$. Quando foi consultado acerca do culto a estes mártires, o Geral Francisco de Borja respondeu: "Estes mártires começaram a ser venerados desde a sua morte, graças à autorização dos bispos e também em Roma. Por indulto da Sé Apostólica, estes mártires começaram a ser venerados com as honras de mártires em muitas praças." ${ }^{17}$

O culto destes quarenta mártires caracterizou-se, desde os seus primórdios, pelo seu carácter internacional. Uma das provas de facto apresentadas pelo postulador Cláudio Bouillaud em 1671 era "a pública voz e fama nunca negada ou colocada em causa" que gozavam estes mártires não apenas nas Índias, como também em Portugal, Espanha, França, Inglaterra, Alemanha, Itália e ainda na Flandres. Tal veneração pública por estes mártires tinha sido referida por dezanove pessoas durante as audições realizadas em Roma ${ }^{18}$. Sobretudo o Decreto de Beatificação de 1854 refere a existência de especiais culto e fama pública destes mártires em Portugal, Brasil, Espanha e Itália ${ }^{19}$.

Naturalmente, este culto afirmou-se desde cedo nas Ilhas Canárias. Segundo se lê no relato de meados do século XVIII por Cesare Cordara, que era então cronista oficial da Companhia de Jesus, pouco depois do massacre, os habitantes de Masso, pequena vila na Ilha de Palma, deliberaram a fundação duma confraria em memória destes homens ${ }^{20}$. Em 1632 os quarenta mártires foram nomeados padroeiros da mesma ilha ${ }^{21}$.

Logo que chegou a notícia do martírio ao Brasil, os cristãos locais começaram a recorrer à intercessão destes jesuítas. Um notório aumento da religiosidade verificado em várias aldeias do Brasil foi atribuído à intercessão dos quarenta mártires. Provavelmente a mesma

${ }^{16}$ Relaçam da gloriosa morte do Padre Inacio de Azeuedo da Companhia de Jesu, p. 265 e Os Quarenta Mártires do Brasil, Relação da Biblioteca da Ajuda sobre o martírio do P. Inácio de Azevedo e seus companheiros, apresentado por Eduardo Brazão, Coimbra, Coimbra Editora Limitada, 1943, p. 44.

17 Leite, Serafim, História da Companhia de Jesus no Brasil, Lisboa e Rio de Janeiro, Portugália e Civilização Brasileira, 1938, vol. Il, p. 264.

${ }^{18}$ AdP, Roma, 13. RISTRETTO del Sommario presentato alla S. Congregatione de Riti L'Anno MDCCLXX. Nella Causa de Venerabili Sevi di Dio IGNATIO di Azebedo, e trenta nove altri della Compagnia di GIESV. Col Fatto, Prove, Oppositioni, Risposte, Miracoli, e Nomi. Dato in LVCE DAL SIGNOR CLAVDIO BOUILLAUD Procuratore della Causa, Roma, Stamperia Della Reverenda Camara Apostolica, 1671, p. 4.

19 Gostaríamos de salientar a prática comum no Brasil e em Portugal de as crianças cantarem as virtudes destes mártires pelas ruas no início do século XVII.

${ }^{20}$ A primeira impressão deste relato data de 1743 e foi da responsabilidade da tipografia António Rossi em Roma (utilizámos neste trabalho a segunda edição de 1854, ou seja, precisamente do ano da beatificação:Cordara, Cesare, Istoria della vita e della gloriosa morte del Beato Ignazio de Azevedo e di altri trentanove beati martiri della Compagnia di Gesù, Roma, Tip. di B. Morini, 1854, p. 142).

${ }^{21}$ Ecribaño Garrido, Julián, El Padre Ignacio de Azevedo y Compañeros «Mártires de Tazacorte», La Palma, Parroquia de San Miguel Arcángel de Tazacorte y Arciprestazgo de los Llanos de Aridane, 1992, p. 12. 
razão e a presença da imagem da Madonna di San Luca (a presença desta imagem na Bahia encontra-se documentalmente comprovada a partir de 1573) ditaram que a primeira celebração em honra dos mártires do Brasil tivesse sido realizada em Salvador da Bahia em 1574. Os mártires foram declarados padroeiros do Brasil na mesma ocasião22.

Em Portugal, o culto destes mártires parece ter sido inicialmente importante sobretudo em Évora. Uma oração composta por um escolástico anónimo do noviciado da mesma cidade, quando soube do "ditoso sucesso", diz o seguinte:

Quanto mais, que outra aução tem Evora, em que faz ventagem a toda a Província; que os dos outros Collegios, quasi todos estam vivos, os deste estam no Ceo, \& deixaram os seus lugares vazios. Pareçeme que ouço aquelles dous innocentisinhos Aleyxo Delgado, \& Pedro Nunes, bradar por seus Mestres, cõdiscipulos, \& Itmãos, que neste Collegio estam. ${ }^{23}$

O sucesso desta devoção na cidade de Évora estará com certeza relacionado com o facto de vários dos mártires de 1570 serem originários ou terem sido noviços na mesma cidade e com a passagem de Maurizio Serpe por Évora, onde lia o seu relato nos refeitórios de padres e noviços jesuítas nos dias do aniversário do martírio ${ }^{24}$.

Várias testemunhas ouvidas durante os processos do Porto (1628) e de Coimbra (1631) mencionaram um culto especial na cidade do Porto pelo jovem mártir António Correia (1553-1570), companheiro de Azevedo e natural da mesma cidade. Uma irmã de António Correia, que era freira beneditina e vivia na década de 1630 na mesma cidade, era conhecida ao tempo como "a Irmã do Mártir"25.

O Bispo de Pamplona, Monsenhor Uriz y Labaryru (1861-1870), obteve de Roma a aprovação da celebração do ofício com festa de Esteban de Zudaire (1551-1570) na diocese de Pamplona a realizar no dia 30 de Agosto $^{26}$.

Bartolomeu Guerreiro, na sua obra panegírica do martírio jesuíta intitulada Gloriosa coroa d'esforçados religiosos da Companhia de Jesu mortos polla fe catholica nas conquistas dos reynos da coroa de Portugal, fez o elogio dos vários mártires companheiros de Inácio

22 Leite, Serafim. História da Companhia de Jesus no Brasil, vol. Il, p. 264 e Leite, História da Companhia de Jesus no Brasil, 1949, Lisboa e Rio de Janeiro, Portugália e Instituto Nacional do Livro, vol. VIII, p. 69.

${ }_{23}$ Franco, António, Imagem da virtude em o noviciado da Companhia de Jesus do Real Colégio do Espírito Santo de Évora do reino de Portugal, na qual se Contém a Fundação, Lisboa, Officina Deslandes, 1714, p. 239.

${ }^{24}$ Gonçalves da Costa, Manuel, Inácio de Azevedo e a Informação da sua morte, in Brotéria 38 (1944), p. 170.

25 ADP.31. Azevedo Processi Originali 1628, Informat.vo Ordina.o in Oporto 1628, f. 9, e AdP, 31. Azevedo Processi Originali 1631, Informativo Apostolico, Coimbra, 1631, ff. 8v, 11v, e www.iberopuebla.edu.mx.

${ }^{26}$ Hernández Palomo, e Osswald, Aspectos del culto a Ignacio de Azevedo y sus treinta y nueve compañeros mártires en 1570. 
de Azevedo, dedicando-Ihes capítulos intitulados "elogios". Na organização destes "elogios" Bartolomeu Guerreiro seguiu critérios variados. Por exemplo, um dos elogios é dedicado aos seis jesuítas Manuel Rodrigues, Manuel Pacheco, Estevam Zuraire, João da Zafra, Marcos Caldeira "designados por Azevedo para animarem os restantes companheiros", enquanto os três companheiros Luiz Correa, Luiz Rodrigues e Manuel Alvares foram honrados no mesmo capítulo, devido ao facto de serem todos naturais da cidade de Évora ${ }^{27}$.

Do ponto de vista da iconografia, existem referências esparsas nos processos de beatificação a quadros com retratos de António Correia. Miguel Leitão de Andrade, primo do mártir Diogo de Andrade, terá visto em 1629 um quadro com o retrato do mesmo Diogo de Andrade na Igreja de São Roque. Diogo de Andrade encontra-se retratado no frontispício duma obra pelo seu primo Diogo de Andrade de $1629^{28}$.

Observa-se, todavia, desde os seus primórdios, uma concentração da hagiografia e da iconografia relativa a este episódio no próprio episódio e na figura do seu líder Inácio de Azevedo. Tal escassez de informação documental explica-se, por um lado, pela extrema juventude de uma grande parte dos companheiros de Azevedo. Por outro lado, uma dispersão devocional e iconográfica poderia constituir uma dificuldade para a sua rápida identificação por parte dos crentes ${ }^{29}$.

\section{A inserção deste episódio na cultura do martírio e a reunião das principais virtudes pós-tridentinas}

Este episódio de 1570 inseriu-se e encontrou uma justificação numa cultura de martírio que ligava o martírio páleo-cristão ao martírio contemporâneo. Neste sentido, a hagiografia realçou o número quarenta. Este número permitiu relacionar este episódio da Época Moderna com o episódio antigo dos quarenta mártires de Sebaste, Arménia, que terá ocorrido entre 316 e 370.

Inácio de Azevedo era descendente de duas das então mais ilustres linhagens nacionais: os Malafaya e os Azevedo, enquanto Francisco Perez Gody era parente de Teresa de Ávila.

No seu relato de edificação, António Cabral Cabral classifica o único jesuíta que foi poupado ao "ditoso sucesso", Juan Sanchez, como rude e porco, tendo sido substituído pelo

27 Guerreiro, Bartolomeu, Gloriosa coroa d'esforçados religiosos da Companhia de Jesu mortos polla fe catholica nas conquistas dos reynos da coroa de Portugal, Lisboa, Antonio Alvarez, 1642, pp. 351-352 e pp. 357-359.

28 Andrade, Miguel Leitão de, Miscellanea do sitio de N. Sa. da Luz do Pedrogão Grande: apparecimto. de sua sta. imagem, fundação do seu Convto. e da See de Lxa com mtas. curiozidades e poezias diversas, Lisboa, Matheus Pinheiro, 1629, p. 100.

29 Hernández Palomo e Osswald, Aspectos del culto a Ignacio de Azevedo y sus treinta y nueve compañeros mártires en 1570. 
jovem "de belíssimo aspecto, naturales e amables prendas Juan de San Juan" ${ }^{\prime 30}$. Esta curiosa e quase divertida afirmação aos olhos dum leitor do século XXI serve-nos para ilustrar a ideia de que a nobreza de sangue ligada à extrema juventude de alguns dos mártires companheiros de Azevedo foi, com certeza, um aspecto que contribuiu para a heroicidade dada a este episódio à época. Estas duas componentes fundamentais da concepção pós-tridentina de santidade foram decisivas para o alto potencial de emulação entre os jovens indiapetae (jovens europeus que escreviam cartas ao Geral da Companhia de Jesus a pedir para serem enviados para as missões das Índias).

Vários missionários mencionavam os quarenta mártires como os modelos a seguir nas suas cartas ou informações ao Geral da Companhia de Jesus. Assim o fez, por exemplo, o P. Gerónimo Pallas para quem:

foi insigne missionário o Padre Inácio de Azevedo, o qual, regressando com o ofício de provincial foi glorioso caudilho de quarenta mártires seus companheiros, que indo para a missão do Brasil foram cruelmente martirizados pelos hereges franceses em ódio da fé que

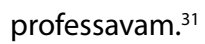

Para além de a sua vida e de o seu martírio exemplares terem inspirado novos indiapetae, alguns dos hagiógrafos dos mártires do Brasil divulgaram episódios relacionando estes mártires com outros mártires jesuítas. Tal foi o caso do paralelismo cronológico errado estabelecido pelo relato de Maurizio Serpe e transmitido a menológios posteriores, segundo o qual o martírio dos cinco jesuítas em Salsete em 1583 teria ocorrido não a 25 de Julho, mas a 15 de Julho, dia do martírio dos quarenta Jesuítas nos mares das Canárias. De igual modo, António Cabral escreveu que o futuro mártir do Japão Marcello Mastrilli teria tido uma visão do episódio de 1570 antes de partir para o Oriente, quando se dirigia em peregrinação ao Santuário do Loreto ${ }^{32}$.

Uma vida em comum feita de oração e práticas pias em Val de Rosal (Caparica) e no barco aparece referida na documentação oficial incluída nos processos preparatórios da beatificação e por isso na cronística ${ }^{33}$. Inácio de Azevedo, Francisco Godoy e António

30 Cabral, Antonio, Relación del martyrio de los quarenta martyres de la Compañia de Jesus: vida del venerable martyr P. Ignacio Acevedo, Madrid, Imprensa y Libraria de Manuel Fernandez, 1744, p. 194.

31 Missión a las Indias por el P. Gerónimo Pallas. De Roma a Lima: La "Misión a las Indias", 1619 (Razón y visión de una peregrinación sin retorno), ed. José J. Hernández Palomo, Madrid, Consejo Superior de Investigaciones Cientificas, 2006, p. 305.

32 Não se encontra tal referência em nenhum dos hagiógrafos clássicos de Marcello Mastrilli.

33 ADP. 16, Summarium Additionale. De Sanctitae Vitae P. Ignatij, \& Sociorum, \& Reliogissima praeparatione ad Aposticam Praedicationem (1-8), ff. 25 e32. 
Correia eram particularmente dados à oração. Azevedo rezava durante muitas horas ao dia e, com frequência, ainda durante a maior parte da noite ${ }^{34}$. Francisco Peres Godoy teria estado nada menos que sete horas seguidas em oração. António Correia teria sido distinguido com uma revelação divina do seu futuro martírio, quando se encontrava, como era seu hábito, em recolhimento e contemplação do Santíssimo Sacramento ${ }^{35}$.

A parte final da vida terrena destes homens, que foi descrita como "mais de anjos do que de homens", ter-se-ia caracterizado ainda por costumes e práticas de pobreza, humildade e sacrifício ou mesmo mortificação. Um episódio, segundo o qual Azevedo teria trocado com uma pobre a sua camisa por roupas andrajosas, foi relatado por testemunhas durante os processos de Braga em 1631 e difundido pela hagiografia de Azevedo, após a sua autenticação pelo Summarium Aditionale de 1671. Em particular, o hagiógrafo francês Gilles François Beauvais, em meados do século XVIII acentuou o carácter de sacrifício ou mortificação deste episódio, quando escreveu que Azevedo teria ficado vários dias ao frio, antes de mandar fazer uma vestimenta de tecidos grosseiros ${ }^{36}$. Um outro episódio que se celebrizou na sua hagiografia foi a história segundo a qual Inácio de Azevedo entrou em Barcelos, levando a pé um jumento montado pelo noviço ${ }^{37}$.

Como escreveu o hagiógrafo António Franco, "em penitências, jejuns, disciplinas e cilícios foi tal o seu excesso [de Azevedo], que se enfraqueceu sobremaneira" ${ }^{\prime 38}$. Azevedo teria afirmado um dia que "não era digno de comer pão alvo, mas que desejava comer pão dos farelos que dão aos cães da casa" ${ }^{\prime \prime 2}$. Reza a hagiografia que durante a sua estadia em Barcelos tinha por hábito distribuir a comida que lhe davam entre os pobres, limitando-se as suas refeições a apenas um bocado de pão de cevada e a uma laranja ${ }^{40}$.

${ }^{34}$ Franco, António, Annus Gloriosus, Viena, typis J.B. Schilgen, 1720, p. 394 e Franco, António, Imagem da Virtude em o noviciado da Companhia de Jesus no Real Collegio de Jesus de Coimbra em Portugal, vol. II, p. 69.

35 Relaçam da Gloriosa Morte, p. 192, Vasconcelos, Simão de, Chronica da Companhia de Jesu do Estado do Brasil e do que obrarão seus filhos nesta parte do Novo Mundo: tomo primeiro da entrada da Companhia de Jesu nas partes do Brasil e dos fundamentos que nellas lançârão \& continuárão seus religiosos, Lisboa, Officina de Henrique Valente de Oliveira, 1663, pp. 397-398 e p. 446 e Franco, António, Beato Inácio de Azevedo e Companheiros mortos; Una gloria de la Iglesia, Braga, Pe. A. Santiago, 1964, p. 37.

${ }^{36}$ Bauvais, Gilles François, La vie du venerable Pere Ignace Azevedo de la Compagnie de Jesus, L'Histoire de son martyre, \& de celui de trente neuf autres de la même Compagnie. Le tout tiré des Procès-verbaux dressés pour leur Canonisation, Paris, Hyppolyte-Louis Guerin, 1744, p. 82.

${ }^{37}$ Franco, António, Imagem da Virtude em o noviciado da Companhia de Jesus no Real Collegio de Jesus de Coimbra em Portugal, vol. II, p. 73.

38 Idem, ibidem, vol. Il, p. 64 .

39 Franco, António, Vida e martyrio do Beato Ignacio de Azevedo e seus bemaventurados companheiros da Companhia de Jesus: extrahida da "imagem da virtude em o noviciado de Coimbra, Lisboa, Administração do "Novo Mensageiro", 1890, p. 4.

${ }^{40}$ Cabral, Relación del martyrio de los quarenta martyres de la Compañia de Jesus, pp. 78-80. 
Maurizio Serpe escreveu que, durante a sua estadia em Val de Rosal, os futuros mártires do Brasil tinham o hábito de andarem vestidos pobremente e pedirem esmola de porta em porta. Todos os companheiros que se reuniram em Val de Rosal vieram a pé e vivendo de esmolas. Muitos jejuavam vários dias por semana, em particular à sexta e ao sábado, praticando ainda disciplinas diárias ${ }^{41}$.

\section{Alguns milagres}

No seu Ristretto Cláudio Bouillaud enunciou quatro milagres post mortem como os milagres oficialmente atribuídos a Inácio de Azevedo e aos seus companheiros mártires. Tratou-se da tão apregoada impossibilidade de os piratas conseguirem tirar a imagem da Madonna di San Luca das mãos de Azevedo morto, do corpo a boiar então considerado contra as leis da Natureza, da história que quatro destes piratas teriam cegado imediatamente, após terem participado na carnificina, e a observação feita por vários navegadores, que o lugar do martírio ganhava, com frequência, uma tonalidade púrpura e um gosto de sangue ${ }^{42}$. As profecias e revelações divinas são milagres muito característicos da concepção pós-tridentina de santidade e que também encontramos nos relatos hagiográficos relativos aos quarenta mártires. Quando se dirigia em 1616 para o Paraguai, onde foi martirizado, o jesuíta Mario Falconi terá tido uma visão do martírio dos quarenta companheiros espeIhado no local onde o mesmo tinha ocorrido. Este episódio foi oficializado enquanto milagre dos quarenta mártires, pois foi referido pelo Postulador Cláudio Bouillard na Compendiaria Collectio apresentada à Sagrada Congregação dos Ritos em 1671 e ainda no Martirologio de Mathias Tanner ${ }^{43}$.

A hagiografia realçou sobretudo episódios de revelação divina do martírio próximo a Inácio de Azevedo, que terão ocorrido não só em terra (Tazacorte e Ilha da Madeira), como no mar. Difundiu-se uma história, que, no barco, Azevedo suspirava continuamente pela morte, dizendo:"Ó meu Deus, se é seguro que irei morrer por Vós! Ó que felicidade! Ó que preciosa morte! Ó que tardam os hereges! Ó quando se delata o meu desejo"44.

Para além de Inácio Azevedo, cinco dos futuros mártires do Brasil foram distinguidos com a revelação divina do seu martírio. Segundo o cronista do Brasil Simão de Vasconcelos, Deus

41 Relaçam da Gloriosa Morte, pp. 201-207.

42 ADP. 13. Ristretto, p. 20.

43 ADP 16. Compendiaria Collectio Summarij exhibiti SAC COMGREG RITVVM Anno 1670. La causa Venerabilis Servis Dei IGNATII AZEBEDI, \& triginta nouem Sociorum è Societ. IESV, ed, Claudio Bouillaud, Roma, Ex Typographya Reuerendae Camerae Apostolicae, 1671, p. 15 e Tanner, Societas lesu usque ad Sanguinis et vitae profusionem militans in Europa, pp. 171 e 177.

${ }^{44}$ Cabral, Relación del martyrio de los quarenta martyres de la Compañia de Jesus, p. 149. 
teria mesmo revelado ao antigo pastor Manuel Álvares a forma como os hereges matariam, ou seja, cortando-Ihe as pernas e os braços, antes de o lançarem ao mar ${ }^{45}$. Por volta de 1640,D. António Pinheiro, Bispo de Miranda, tinha o hábito de pregar as revelações consideradas sinais sobrenaturais, com as quais teriam sido distinguidos Inácio de Azevedo, Nicolau Diniz, António Correia, Manuel Alvarez, Estêvão Zuraire e Marcos Caldeira ${ }^{46}$. Como se encontra referido pela Acta Beatificacionis, 1853, nos processos de Évora de 1631 o P. Fernando Rebelo SJ, visitador do Colégio de Bragança, tinha testemunhado acerca da visão do P. Diniz e ainda que tinha visto vários quadros mostrando o P. António Correia de joelhos perante o Santíssimo Sacramento, simbolizando com isso a revelação que Correia teria tido do seu martírio, quando se encontrava em adoração ao Santíssimo ${ }^{47}$.

Azevedo não só morreu no mar, como dois dos cinco milagres mais comuns e atribuídos pela hagiografia à sua actividade in vitam teriam ocorrido num contexto marítimo. Durante uma travessia do Rio Prado a caminho de Barcelos, Inácio de Azevedo teria salvo o barco onde seguia do naufrágio certo, ao afastar com um simples gesto da mão um tronco gigantesco ${ }^{48}$. O mesmo episódio aparece referido em sentido inverso em alguns relatos ${ }^{49}$.

Quando Inácio de Azevedo fazia a travessia por mar entre São Vicente e a Bahia em Julho de 1567, teria conseguido evitar um naufrágio certo, acalmando uma baleia que se preparava para cuspir água para cima do barco onde viajavam Azevedo, Anchieta, Nóbrega e o Bispo do Brasil, Pedro Leitão. Este milagre é normalmente atribuído a Anchieta.Todavia, em alguma literatura coeva, Anchieta atribui o mesmo milagre a Azevedo. Cabral citou assim uma carta de Anchieta, na qual o mesmo Anchieta, conhecido pelas suas capacidades taumatúrgicas, relaciona esta salvação milagrosa com a presença a bordo de Inácio de Azevedo:

nos miraban desde la nao el señor Obispo, y todos los astros con compasión, dandones y mirandones como perdidos. Solo confiaban en Dios, y en su Majestad esperaban, que nos libraria con poderosa mano, porque en aquel batel venia con nosotros aquel tan caro amigo de Dios P. Ignacio Acevedo. ${ }^{50}$

45 Vasconcelos, Chronica da Companhia de Jesu do Estado do Brasil, p. 442.

${ }^{46}$ AdP 17. Brasilien. Canonizationes, seu declarationes Martirij Servorum Dei Ignatij Azevedi, \& triginta octo Sociorum è Societate lesu, \& alterius Adaucti.: Informatio D. Jo. Bottinii Sac. Consistorii advocati, cum responsionibus iuris ad oppositiones R. P.D. Fidei Promotonis, Romae, 1671, pp. 33-38.

47 AdP. 20, Acta Beatificacionis, Roma, 1713-1853.

48 AdP 4., Brasilien Canonizationis Servi Dei Ignaty Azevedi et Sociorum Martyrum e Societate IESU Processus añcte apostolica fabricatus in Civitat.e Coimbra anno 1631,f. 89 e Franco, Imagem da Virtude em o Noviciado da Companhia de Coimbra, vol. II, p. 71.

49 Cabral, Relación del martyrio de los quarenta martyres de la Compañia de Jesus, pp. 81-82.

50 Cabral, Relación del martyrio de los quarenta martyres de la Compañia de Jesus, p. 107. 


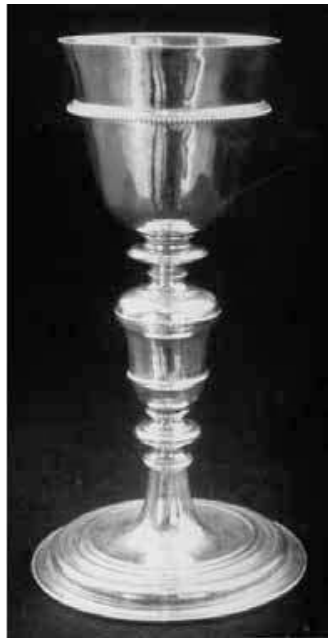

6. Cálice, prata dourada, ermida de São Miguel de Tazacorte, Canárias. (Cortesia de José Hernández Palomo.)

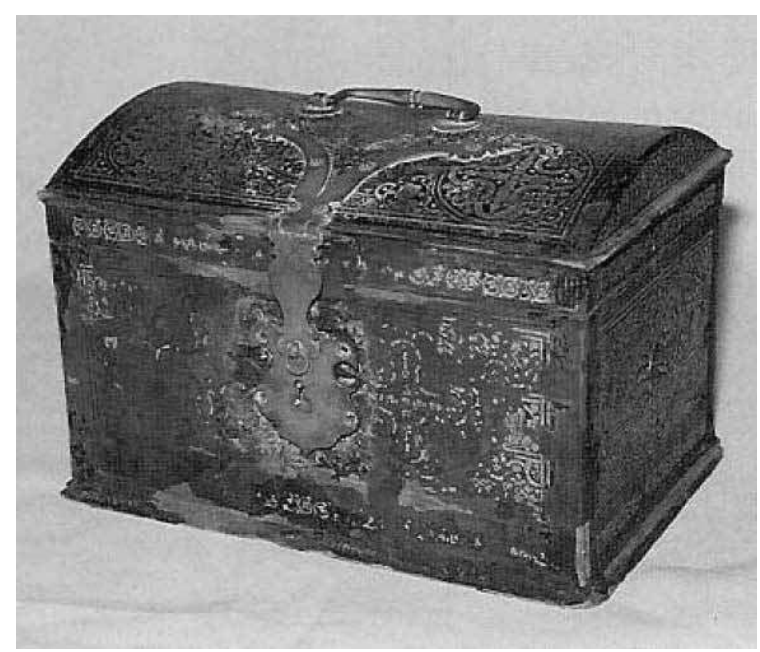

7. Cofre que, segundo a tradição local, conterá alguns objectos litúrgicos oferecidos por Inácio de Azevedo, couro e tecido. (Cortesia de José Hernández Palomo.)

De igual modo, Simão de Vasconcelos escreveu:

E atribuindose commummente a milagre a intercessam de loseph, o humilde servo o atribue ao Padre Ignacio, \& mais companheiros, dizendo assi: Estava o Bispo, \& os mais do nauio a la mira, esperando o sucesso com grande temor; mas confiados que não perigariam, por hir allì o Padre Ignacio com seus companheiros..$^{51}$

\section{A veneração pelas escassas relíquias e pelos lugares associados a estes mártires}

(Fig. 6) Um dos problemas encontrados pelos responsáveis jesuítas interessados em fomentarem este novo culto foi a escassez de relíquias. Entre os raríssimos objectos ligados a estes mártires, destaca-se o cálice conservado na Capela de São Miguel de Tazacorte, com o qual Inácio de Azevedo teria celebrado a sua última missa em Tazacorte no dia 13 de Julho de 1570. De acordo com a lenda hagiográfica, foi exactamente ao beber deste

51 Vasconcelos, Simão de, Vida do P. Joseph Anchieta, Rio de Janeiro, Imprensa Nacional, 1943, p. 113. 
cálice que Inácio de Azevedo teria tido uma visão do seu martírio próximo. Esta visão ter-lhe-ia causado uma tal impressão, que teria mordido com enorme força o bordo do cálice, deixando assim uma marca dos dentes no mesmo ${ }^{52}$

(Fig. 7) Um outro objecto, mais concretamente, um cofre igualmente conservado na Ermida de São Miguel de Tazacorte, guardará alguns objectos litúrgicos que Inácio de Azevedo teria oferecido ao seu amigo Melchior de Monteverde y Pruss, seu anfitrião durante a sua curta estadia em Tazacorte ${ }^{53}$.

Entre os pouquíssimos objectos que teriam sido salvos da "fúria herética" encontrar-se-ia uma sotaina usada por um dos mártires. Lemos no Processo de Coimbra de 1631 que uma testemunha tinha ouvido de Diego de Roas, Senhor da Ilhas de Hierro e Gomera, Canárias, que o seu pai tinha conseguido obter uma sotaina dos corsários. Em finais do século XVIII esta sotaina era objecto de devoção especial na Ilha de Gomera ${ }^{54}$.

O cronista Giulio Cesare Cordara considerou mesmo que tenha existido mais do que uma sotaina à veneração pública em Gomera, quando afirmou:

O Governador de Gomera distribuía vestes como relíquias dos mártires para sua veneração em toda a Ilha. Foi tanto fervor aceso nestes cidadãos que muitos escreveram cartas ao Sumo Pontífice pedindo canonização formal dos mártires, sendo então eleitos por protectores..$^{55}$

Em Portugal, duas cruzes que estariam ligadas aos mártires foram, por isso, consideradas objectos de especial devoção. A cruz, junto à qual os futuros mártires se dirigiam em oração durante a sua estadia em Vale de Rosal, constituía uma inestimável relíquia. António Franco, no início do século XVIII, afirmou que esta cruz tinha sido transportada para a Capela de Santo Antão, em Lisboa, pouco tempo antes de escrever a obra Imagem de Virtude no Noviciado de Coimbra. Em 1659 um procurador do Brasil tinha mandado erguer uma cruz em mármore no local onde se encontrava antes a cruz visitada pelos mártires ${ }^{56}$.

52 Rumeau de Armas, Antonio, La expedición misionera al Brasil martirizada en aguas de Canarias (1570), in Missionalia Hispânica, 11 (1947), p. 340.

53 Las Casas, José Apolo, Piratas de los siglos XVI y XVII en aguas de Canarias - Los Mártires de Tazacorte, Madrid, Magisterio Español, 1943, pp. 28-29.

${ }^{54}$ Vera y Clavijo, José, Noticia de la historia general de las Islas Canarias, Madrid, Imprenta Blas Román, 1776, tomo III, p. 29.

55 Cordara, Istoria della vita e della gloriosa morte del Beato Ignazio de Azevedo, p. 142.

56 Franco, Imagem da Virtude em o noviciado da Companhia de Jesus no Real Collegio de Jesus de Coimbra em Portugal, vol. II, pp. 84 e 90 e Gonçalves da Costa, Manuel, Inácio de Azevedo - O homem e a sua época (1526-1570), Braga, Livraria Cruz, 1957, p. 363. 
Antonio Cabral dá-nos, todavia, uma versão bem diferente. Cabral relata que esta cruz tinha sido dividida em fragmentos vários, que se encontravam na época em posse dos colégios jesuítas da Bahia, de Coimbra e ainda em Vale de Rosal ${ }^{57}$.

Conta-se que, por milagre, um raio que caiu na capela onde se guardava esta cruz não fez quaisquer estragos ao altar-mor e às imagens na capela. A este episódio deve-se a criação da fama destes mártires como padroeiros contra o fogo e outras intempéries naturais. Os mártires passaram a ser considerados advogados contra as tempestades, sendo imagens suas, por isso, colocadas nos lugares mais expostos às intempéries da Natureza ${ }^{58}$.

Uma tradição circulando na Idade Moderna na Madeira dizia que Azevedo e os seus futuros companheiros de martírio tinham estado na Quinta do Pico do Cardo, onde tinham colocado uma cruz actualmente desaparecida. O P. Luiz Severim escreveu em 1683 que mandara fazer um retábulo para a imagem de Nossa Senhora de San Luca deixada por Azevedo ao colégio e novo caixilho para a mesma cruz. Em 1743, o P. Manuel Lobo, reitor do Colégio do Funchal, mandou erguer uma cruz para substituir a cruz tresladada ${ }^{59}$.

Alguns dos locais onde os mártires passaram desenvolveram-se em lugares de peregrinação. O Summarium de 1671 destacou os relatos de várias pessoas ouvidas durante os processos da Bahia e que tinham referido uma grande devoção por alguns dos lugares que os mártires teriam frequentado durante a sua estadia na llha de Palma ${ }^{60}$.

Finalmente, uma imagem de Nossa Senhora (provavelmente da Madona di San Luca) que existia na capela do Noviciado da Companhia de Jesus em Évora em meados do século XVII era objecto de especial devoção. Esta imagem tinha sido oferecida pelo P. Inácio de Azevedo e era da da autoria do Irmão Juan Maiorga, companheiro-mártir de Azevedo ${ }^{61}$.

\section{A literatura hagiográfica}

O texto escrito e muitas vezes impresso foi, sem dúvida, um aspecto fundamental no fomento do culto destes quarenta mártires. Compreensivelmente, os principais cronistas das Províncias jesuítas de Portugal, Brasil e Castela deram especial relevo a este episódio ${ }^{62}$.

57 Cabral, Relación del martyrio de los quarenta martyres de la Compañia de Jesus, p. 129.

58 Cabral, Relación del martyrio de los quarenta martyres de la Compañia de Jesus, p. 131.

59 Biblioteca Pública Municipal do Porto [BPMP]:Manuscr. 162: Chronica dos PP. Jezuitas de Portugal, finais séc. XVII/,ff. 833-835, e Domingues, Ernesto, Raízes terrestres de 40 mártires, Braga, Sep. Mensageiro, 1971 , p. 9.

60 AdP. 16, Summarium Aditionale (1671), f. 163.

61 Franco, Imagem da virtude em o noviciado da Companhia de Jesus do Real Colégio do Espírito Santo de Évora, p. 368.

62 Teles, Baltasar, Chronica da Companhia de Jesu, na Provincia de Portugal; e do que fizeram, nas conquistas d'este Reyno, os religiosos, que na mesma Provincia entràram, nos annos em que viveo S. Ignacio de Loyola, 
A inclusão deste episódio nas crónicas das missões da Companhia de Jesus no Oriente a partir da crónica pelo italiano Giovanni Pietro Maffei de 1573 parece-nos sinal inequívoco da especial importância deste episódio para a história da Companhia latum sensum ${ }^{63}$.

Ainda da década de 1570 data a relação mais antiga deste martírio pelo P. Maurício Serpe (esta obra foi escrita em duas fases, ou seja, entre 1571 e 1572 e entre 1574 e 1575) ${ }^{64}$, que se baseou no testemunho presencial de João Sanches, único jesuíta poupado à morte, devido a ser cozinheiro. Esta relação, ou seja, duas versões deste relato, foram apenas publicadas no século $X X^{65}$.Todavia, os principais autores que trataram o episódio tiveram acesso ao mesmo relato, como podemos ler na crónica do noviciado de Coimbra pelo P. António Franco:

Temos desta matéria huma devota Historia escrita pelo Padre Mauricio, Confessor Del-Rey Dom Sebastião, da qual ainda que se aproveitaraõ, os que destes gloriozos Martyres escreverão, sempre foi muito pollo grosso, (...). ${ }^{66}$

$\mathrm{Na}$ origem da emulação de muitos indiapetae antes mencionada encontra-se uma estratégia de fomento deste culto entre os noviços e colegiais. Dentro da Companhia este culto foi fomentado, entre outras medidas, através da introdução deste episódio nos menológios ou catálogos, que eram lidos nos aniversários dos jesuítas ilustres, após a leitura da Sagrada Escritura ${ }^{67}$.

Em termos gerais, este culto foi objecto até ao século XIX duma ampla variedade e quantidade de bibliografia. Em particular, o postulador da causa Cláudio Bouillaud, autor do Ristretto del Sommario apresentado à Sacra Congregação dos Ritos em 1671, informa-nos que o tema foi tratado por noventa e seis autores entre 1572 e $1665^{68}$.

O tema interessou igualmente a autores fora da própria Companhia, entre eles, o cronista do Rei de Espanha, António Herrera, parte 2, libro 1, cap. 17, facto que aparece,

Vasconcelos, Chronica da Companhia de Jesus do Estado do Brasil, Lisboa, Paulo Craesbeeck, 1645-1647, 2 vols. e Alcazar, Bartholomé, Chrono-historia de la Compañia de Jesus, en la Provincia de Toledo y elogios de sus varones, Madrid, Juan Garcia Infançon, 1710.

${ }^{63}$ Maffei, Giovanni Pietro, Rerum a Societatis lesu in Oriente gestarum volumen primum, Nápoles, aedibus Decii Lachaei, 1579, pp. 230-233.

${ }^{64}$ Gonçalves da Costa, Inácio de Azevedo e a informação da sua morte, p. 170.

${ }^{65}$ Ver nota 16.

${ }^{66}$ Franco, Imagem da Virtude em o Noviciado da Companhia de Jesús de Coimbra, vol. II, p. 80.

${ }^{67}$ Ver, por exemplo, na Biblioteca Nacional de Portugal [BNP], FG. Ms. 1647, Catalogo di alcuni martírio e uomini insigni dellaCompagnia di Gesù, che si legge dopo la Sacra Scrittura secondo l'ordine dei giorni nel refettorio della Casa Professa di Roma, Évora, nell'anno 1759.

${ }^{68}$ AdP. 13. Ristretto, pp. 12-13. 
aliás, incluído como prova de facto no Ristretto del Sommario em $1671^{69}$. Parece-nos particularmente ilustrativo da rápida ressonância que este episódio teve na altura o facto de o mesmo episódio ter sido narrado por várias histórias do mundo, a partir da obra do autor italiano Lorenzo Surius, Commentarius brevis rerum in orbe gestarum ab anno 1500. Usque in anno 1574. ex optimis quibusque scriptoribus congestus, Colónia, Johann Erben, 1578.

A biografia De Vita et morte P. Ignatii Azevedii et sociorum eius e Societate lesu, da autoria do italiano Pedro Possino, que foi publicada em Roma em 1679, foi a primeira biografia impressa dos mártires ${ }^{70}$. No entanto, a primeira biografia do Geral Francisco de Borja pelo biógrafo mais importante da Velha Companhia, o P. Pedro Ribadeneira, que é datada de 1594, menciona o martírio dos quarenta jesuítas a caminho do Brasil ${ }^{71}$. A partir de Ribadeneira, os biógrafos de Borja vão por norma incluir este martírio. Em especial, as obras de edificação pelo jesuíta António Franco constituem um manancial de informação fundamental em relação aos quarenta mártires.

O tema foi naturalmente destacado pelos principais autores dos martirológios jesuítas, entre eles Richard Verstegen, Philip Alegambe e obviamente o português Bartolomeu Guerreiro, que aliás tinha sido ouvido como testemunha durante os processos relativos à beatificação dos quarenta mártires realizados em Évora em $1631^{72}$. Gostaríamos sobretudo de salientar que o principal martiriológio jesuíta de toda a Época Moderna, o martirológio de Mathias Tanner, contém uma gravura colectiva do martírio e ainda uma gravura de Inácio de Azevedo sozinho ${ }^{73}$.

A devoção mariana de Inácio de Azevedo, que se teria manifestado desde a sua infância, e sobretudo a importância deste mártir na difusão do culto da Madonna di San Luca foram provavelmente os factores que determinaram a inclusão deste episódio de martírio em calendários marianos, tais como o Calendario Virginiis de Antonius de Balinghaen e

69 Idem, ibidem, p. 4.

70 Possino, Pietro, De vita et morte P. Ignatii Azevedii et sociorum eius e Societate lesu, Roma, ex typographia Varesij, 1679.

${ }^{71}$ A edição por nós consultada na preparação do presente texto foi uma edição de 1945: Ribanedeira, Pedro de: Vida del P. Francisco de Borja, in Historias de la Contrarreforma: vida de los Padres Ignacio de Loyola, Diego Laínez, Alfonso Salmerón y Francisco de Borja. Historia del cisma de Inglaterra. Exhortación a los capitanes y soldados de La Invencible, ed. Eusebio Rey, Madrid, 1945, pp. 781-787.

72 Alegambe, Philippe, Mortes illustres et gesta eorum de Societate lesu. Extremos aliquot annos, mortesque illustres usque ad annum MDCLV adiecit loannes Nadasi, Roma, ex typographia Varesij, anno 1657, p. 49, Verstegen, Richard, Theatrum Crudelitatum Haereticorum nostri Temporis. Antuérpia, Adrianum Huberti, 1588, p. 54 e Guerreiro, Bartolomeu, Gloriosa coroa d'esforçados religiosos da Companhia de Jesu mortos polla fe catholica, pp.331-359.

73 Tanner, Societas lesu usque ad Sanguinis et vitae profusionem militans in Europa, pp. 174 e 178. 
o Hortus Marianus de François de La Croix ou outras obras de devoção mariana como o Giardinetto della Madonna de Ludovico Florio $^{74}$.

O tema encontrou igualmente um importante eco na poesia jesuítica. José de Anchieta, que era natural das Canárias e conheceu Inácio de Azevedo no Brasil, compilou o Cancioneiro dos Mártires do Brasil. Trata-se de dois poemas dedicados aos mártires do Brasil, dois poemas dedicados a Inácio de Azevedo, um poema dedicado ao seu companheiro Manuel Álvares e ainda dois poemas honrando o grupo de onze jesuítas dirigidos por Pedro Diaz que foram martirizados um ano depois no mar, igualmente a caminho do Brasil $^{75}$.

No contexto europeu, o jesuíta e poeta italiano Francesco Benci compôs um poema em memória destes mártires, o qual incluiu na sua obra em honra dos mártires de Salsete de Goa $(1583)^{76}$. O hagiógrafo italiano Antonio Rossi publicou em 1743 uma laude composta pelo P. Juan Madureira morto pela sua fé nas Costas da Inglaterra em $1601^{77}$. Nas listas de documentação relativas aos mártires e conservadas no Archivio della Postulazione são ainda referidos um epigrama que terá ficado manuscrito pelo P. Adriano da Bologna em honra de Azevedo e ainda um poema pelo alemão Andreas Kanon, ambos de meados do século $\mathrm{XVII}^{78}$.

Destaca-se o autor Gerardo Van den Berghe Montanus (conhecido igualmente como Gerardo Verga, Montanus ou Oranus), que juntou à colectânea latina de Cícero um epigrama sobre cada um dos mártires de 1570 e ainda sobre o P. Miguel Aragonês morto com P. Diaz no ano de 1571. Estes epigramas tiveram uma enorme divulgação até ao século XVIII, como demonstram as suas sucessivas reedições a partir de $1623^{79}$.

74 Balinghaen, Antonious de, Kalendarium SS. Virginis Dei Genitricis Mariae, Duaci, Ex Typographia Balthazaris Belleri, 1629, p. 348, De la Croix, Hortulus Marianus, Duaci, Typ. B. Belleri, 1622, p. 50 e Ludovico Florio, Giardinetto della Madonna, Roma, Il Mascardi, 1641, p. 65.

75 Este cancioneiro foi publicado integralmente por Armando Cardoso em 1984. (P. Joseph Anchieta, obras completas, introdução e notas por Armando Cardoso, São Paulo, Loyola, 1984, 3 vol., pp. 92-100.)

76 Benci, Francesco, Poëmatis de quinque martiryribus, Roma, Typographia Vaticana, 1592, libro 3, p. 196.

77 Juan Madureira foi muito importante na vida de Inácio de Azevedo, pois convenceu Inácio de Azevedo a realizar os Exercícios Espirituais em Coimbra, após os quais Inácio de Azevedo entrou na Companhia de Jesus. (Rossi, António, Relazione della vita, e martirio del venerabil Padre Ignazio de Azevedo ucciso dagli eretici con altri trentanove della Compagnia di Gesú, Roma, Stamperia di Antonio dé Rossi, 1743, p. 177 e Teles, Chronica da Companhia de Jesu, na Provincia de Portugal; vol. I., p. 271.)

78 Bologna, Adriano da, Epigrammatum, Tournai, 1642, epig. 159, f. 154 e Kanon, Andreas, Lirici, Cracóvia, Christoph Schedel, 1642, Lib. 4, Ode 15.

79 M. T. Ciceronis Orationis selectae duodecim, cum Libris de Amiticia, Senectute, Paradoxis et ex Epistolis aliquot. Metaphasis poética in Canticum Canticorum. Centuria Epigrammatum in Martyres Societatis, Madrid, Luiz Sanchez, 1623 e Escalera, Juan, Berghe (Montanus), Gerardo Van den, in Diccionario histórico de la 
De igual modo, é fundamental referir a inclusão destes poemas em duas crónicas de províncias jesuítas. Simão de Vasconcelos escolheu introduzir os poemas dedicados a Inácio de Azevedo e ao seu companheiro e pastor-mártir Manuel Álvares na sua crónica da Província do Brasil ${ }^{80}$. Por sua vez, Bartholomé Alcazar, na sua crónica da Província Jesuítica de Toledo, publicou todos os poemas de Montanus em honra dos mártires companheiros de Azevedo e de nacionalidade espanhola ${ }^{81}$.

Finalmente, este martírio foi tratado pelo teatro da Companhia de Jesus. O V acto da peça de Vincenzo Guiniggi Ignatius in Monte Serrato, levado à cena em 1623 em Roma, é dedicado a Inácio de Azevedo. Compreensivelmente, os mártires foram sobretudo destacados pela coreografia das festas portuguesas da dupla canonização de 1622. Em Lisboa, uma das carroças representava uma nau desfilando pela cidade e carregada com os figurantes dos santos mártires da Companhia comandados por Inácio Azevedo e António Criminale, o primeiro jesuíta mártir do Oriente em $1546^{82}$.

\section{A iconografia (alguns dados histórico-hagiográficos e principais protótipos)}

O espólio iconográfico deste martírio anterior ao século XIX é, na actualidade, reduzido. Limita-se essencialmente a alguns quadros e a gravuras representando Inácio de Azevedo ou o martírio colectivo, e ainda inserido em representações panegíricas colectivas de membros da Companhia de Jesus.

(Fig. 8) Entre estas últimas, destacamos o célebre tecto da sacristia do antigo colégio jesuíta de São Salvador da Bahia, Brasil, pintado entre 1683 e 1694 e as assim chamadas galerias de mártires já referidas ${ }^{83}$.

Compañía de Jesús: biográfico-temático, Charles E. O’Neill, S.I., Joaquín M. Domínguez, S.I. (Directores), Roma, Institutum Historicum Societatis lesu, 2001, vol. I, p. 415.

80 Vasconcelos, Chrónica da Companhia de Jesus do Estado do Brasil, p. 446.

81 Alcazar, Bartholomé, Chrono-historia de la Compañia de Jesus, en la Provincia de Toledo, vol, I, pp. $317-318$.

82 Relaçam Geral da Festas que fez a Companhia de Jesús na Provincia de Portugal, na canonização dos gloriosos Sancto Ignacio, \& S. Francisco Xavier Apostolo da India Oriental no anno de 1622, Lisboa, Pedro Craesbeeck, 1623, f. 24, Relacion de las fiestas, que la Compañia de Jesu haze en la ciudad de Lisboa a la canonizacion de S. Inacio de Loyola y de S. Francisco Xavier: comiençanse en 30. de Julio, y acabanse en 7. de Agosto, Lisboa, Geraldo de la Vinha, 1622, f. 5, e Osswald, Iconografia das Cerimónias de Canonização no contexto português, p. 338.

${ }^{83}$ Moura Sobral, Luís de, Espiritualidade e propaganda nos programas iconográficos dos Jesuítas Portugueses, in A Companhia de Jesus na Península Ibérica nos sécs. XVI e XVII, Porto, Instituto de Cultura Portuguesa da Faculdade de Letras da Universidade do Porto/Centro Interuniversitário de História da Espiritualidade da Universidade do Porto, 2005, pp. 411-415. 
Não obstante a lamentável escassez iconográfica actual deste martírio, a pesquisa realizada até ao momento permite-nos afirmar que os jesuítas, como era aliás apanágio seu, usaram a representação artística deste martírio como instrumento fundamental na difusão do mesmo durante a Época Moderna. A sua difusão iconográfica iniciou-se logo após o evento. $\mathrm{O}$ primeiro retrato post-mortem de Inácio de Azevedo foi provavelmente um retrato encomendado pelo seu irmão Jerónimo de Azevedo ao ser informado do martírio de Inácio ${ }^{84}$. Mais impacto teve, sem dúvida, uma relação ilustrada com gravuras e encomendada pelo Geral Francisco de Borgia, pois sabe-se que esta relação teve uma ampla difusão dentro e fora da Companhia ${ }^{85}$.

Com autorização do Papa Gregório XV, imagens destes mártires com suas insígnias e atri-

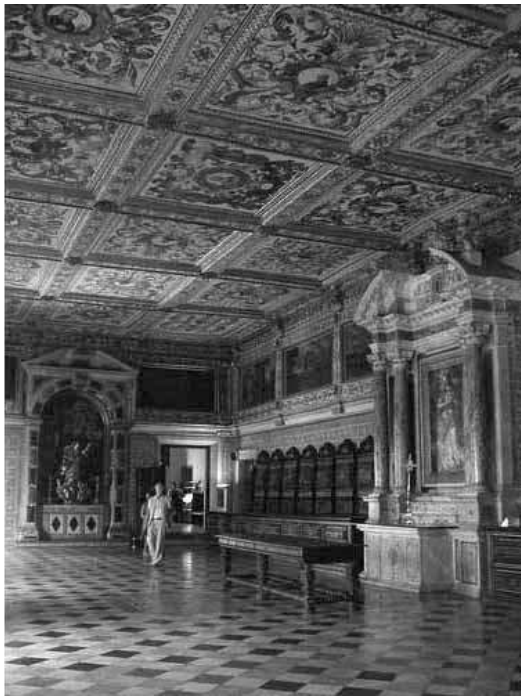

8. Autor anónimo, tecto da sacristia da actual catedral e igreja do antigo colégio da Companhia de Jesus em Salvador da Bahia, óleo, entre 1683 e 1694 (cortesia de A. Silva). butos passaram a ser objecto de veneração no il Gesù, igreja principal da Companhia de Jesus, assim como em várias outras igrejas jesuítas, até que os decretos de Urbano VIII em 1625 obrigaram à distinção entre santos canonizados e não canonizados ${ }^{86}$. Esta limitação foi, todavia, alterada no século seguinte. Em 1742, o Papa Bento XIV ordenou a multiplicação ilimitada das imagens deste martírio para fomentar o culto a estes mártires, devido à escassez de relíquias ${ }^{87}$.

Durante os processos de Coimbra em 1631, treze pessoas testemunharam positivamente ao quesito se sabiam "que forão pintados com as insígnias do martírio e seus nomes esculpidos e como os sabe". Cinco destas testemunhas referiram uma reacção de grande devoção suscitada entre os crentes pelos quadros e gravuras destes mártires. Estas imagens eram uma fonte de tal emoção entre os crentes, que chegavam a suscitar as suas lágrimas ${ }^{88}$. Aliás, referências a retratos pintados, esculturas e gravuras destes mártires abundam nos textos de todos os processos de beatificação.

${ }^{84}$ Cabral, Relación del martyrio de los quarenta martyres de la Compañia de Jesus, p. 212.

${ }_{85}$ Cordara, Istoria della vita e della gloriosa morte del Beato Ignazio de Azevedo, p. 6.

${ }^{86}$ Idem, ibidem, pp. 228-229.

87 AdP.20 Brasilien. Redingrationis Cultus Ven. Servorum Dei Ignatii de Azevedo et XXXIX. Sociorum Martyrium, f. 27.

${ }^{88}$ Domingues, Ernesto, Inácio d'Azevedo Retratos e Parentes, separata do Arquivo dos Jesuítas, 1977, s/p. 


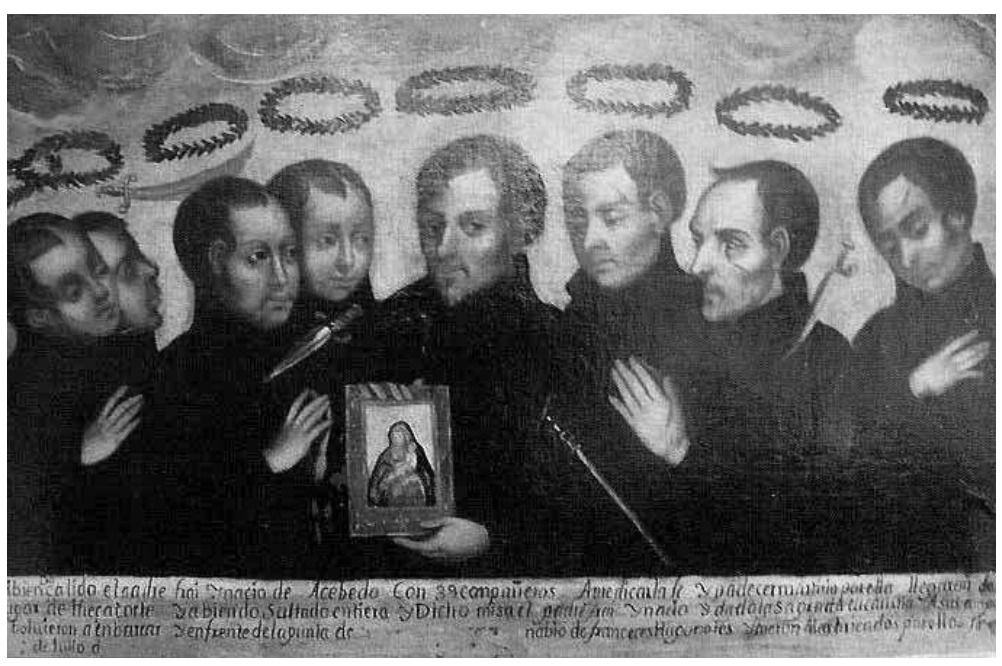

9. Pintor espanhol, Inácio de Azevedo e companheiros mártires, século XVII, Ermida de São Miguel de Tazcorte (cortesia de José Hernandez Palomo).

(Fig. 9) Coincidência ou não, de visita às Ilhas Canárias entre 1631 e 1633, ou seja, na altura em que decorriam os primeiros processos de beatificação destes mártires, O P. Alonso Cano deu-se conta de que apenas alguns anciãos conheciam ainda a história do martírio de 1570. Por essa razão, este jesuíta decidiu encomendar a pintura dum óleo com o mesmo tema, actualmente desaparecida, mas que influenciou três quadros nas igrejas de São Miguel de Tazacorte, São Salvador de Santa Cruz en La Palma e no Museu Diocesano de Arte Sacra da Catedral de Santa Ana de Las Palmas ${ }^{89}$.

Os jesuítas em Roma demonstraram igualmente um interesse imediato pela representação artística deste martírio. Destacam-se neste contexto as gravuras com este martírio que decoram os frontispícios das vitae de Inácio de Loyola e Francisco Xavier impressas em 1622 para comemorar a canonização de Inácio de Loyola e Francisco Xavier. Merece ainda menção o facto de que Inácio de Azevedo segurando a imagem da Madonna di San Luca nas mãos foi esculpido entre os membros mais distintos da Companhia de Jesus na parte fron-

${ }^{89}$ Escudero,José Guilherme,Los Mártires deTazacorte:Los cuadros de El Salvador, 12 din Anchieta Red lgnatiana de Canárias, 12 de Julho de 2007, in http://redanchieta.org/ e Fraga González, Cármen, Iconografia de los PP. Azevedo y Anchieta, y del Hermano Pedro de Bethencourt, in Colóquio de História Canária Americana, 1977, pp.445-452. 
tal do túmulo de Santo Inácio de Loyola na Igreja de II Gesù em 1637 pelo escultor Alessandro Algardi ${ }^{90}$.

Este grupo de mártires tornou-se modelo iconográfico e devocional favorito para representar e emular os inúmeros mártires e membros da Companhia durante a Época Moderna. Em Roma estes mártires foram com frequência os mártires plasticizados pela arte para criar novas vocações de missionários prontos a morrerem ad maiorem Dei gloriam. Neste sentido, surgem nos processos de beatificação e em biografias de muitos indapetae e futuros mártires [entre eles, os dois futuros mártires do Japão Carlo Spínola (1622) e Marcello Mastrilli (1637), traziam consigo estampas dos mártires de 1570]191.

(Fig. 10) De igual modo, um quadro a óleo com este martírio foi pendurado antes de 1597 no noviciado de Sant'Andrea al Quirinale, fazendo pendant

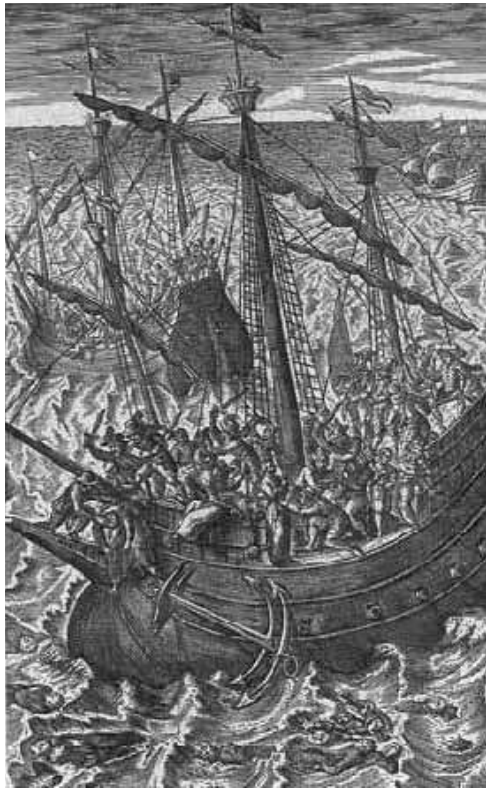

10. Gravura em Louis de Richeome, 1611 (cortesia de Christoph Nebgen). com um quadro que representava o Martírio dos cinco jesuítas de Salsete em 1583. Este quadro encontra-se reproduzido numa gravura ilustrando a obra do jesuíta francês Louis de Richeome intitulada La Peinture Spirituelle ou l'art d'admirer, aimer et louer Dieu en toutes ses oeuvres, et tirer de toutes profit saluter, e que contém a descrição dos ciclos pintados no Noviciado de Sant'Andrea Quirinale antes de $1597^{92}$. À semelhança do ciclo de San Tommaso di Canterbury, este ciclo de pinturas de Sant'Andrea al Quirinale é tanto mais interessante pela sua contemporaneidade. O famoso iconógrafo francês de arte cristã Emile Mâle fez aliás a sugestão de que o quadro com o chamado episódio dos Quarenta Mártires do Brasil (1570) que se encontrava na sala de estar tenha sido pintado pouco tempo depois da sua ocorrência ${ }^{93}$.

90 Bricarelli, Carlo, Alcune Sculture all'altare di Sant'lgnazio nel Gesù di Roma, in La Canonizzazione dei Santi Ignazio di Loiola Fondatore della Compagnia di Gesù e Francesco Saverio Apostolo dell'Oriente, ed. Comitato Romano Ispano per le Centenarie Onoranze (ed.), Roma, Grafia, 1922, p. 113.

91 Spinola, Fabio Ambrosio, Vita P.Caroli Spinola, Roma, Francesco Corbelletti, 1627, p. 183 e Cinami, Leonardo, Vita Patris Marcello Franciscii Mastrilli, Viterbo, Diotallevi, 1645, p. 13.

92 Osswald, Maria Cristina, A iconografia do martírio para a Companhia de Jesus entre os sécs. XVI e XVIII, in Revista Portuguesa de Filosofia (no prelo).

93 Mâle, Emile, L'Art Religieux après le Concile de Trente, etude sur l'iconographie de la fin du XVI siècle, du XVII, du XVIII siècle; Italie, France, Espagne, Flandres. Paris, Collin, 1932, p. 118. 
O Geral Nickel Oliva encarregou o célebre pintor de batalhas marítimas Giacomo Cortese (1621-1676), conhecido como II Borgognese, após este ter entrado no mesmo noviciado em 1657, de pintar um óleo com este martírio ${ }^{94}$. Este quadro, que foi a última obra de II Borgognese, encontra-se na colecção do Palazzo del Quirinale em Roma.

Inácio de Azevedo, sozinho ou acompanhado pelos restantes companheiros de martírio e vestidos com a tradicional sotaina, segura a imagem de Nossa Senhora de S. Luca que em alguns casos é ainda destacada pelo tamanho demasiado grande em relação ao dos mártires. Em todas as imagens que conhecemos Inácio de Azevedo tem sempre barba para mostrar a sua meia-idade à data da morte em comparação com a já antes referida extrema juventude de quase todos os seus companheiros (os únicos dois sacerdotes jesuítas de quatro votos a bordo eram Inácio de Azevedo e Diogo de Andrade).

Nas representações colectivas deste martírio, encontramos duas iconografias principais. Um destes modelos ilustra o próprio episódio do martírio em que se vêem os mártires a serem torturados, mortos e lançados ao mar. A partir da gravura ilustrando a obra do jesuíta francês Louis de Richeome, verifica-se que em várias imagens alguns dos mártires no mar têm os braços levantados, representando os mártires que foram lançados ainda vivos ao mar ${ }^{95}$. Entre as representações colectivas do martírio de 1570 podemos ainda inserir as representações mostrando a visão de Teresa de Ávila em simultâneo com este episódio de martírio e em muitas das quais os mártires já aparecem glorificados no céu e a serem coroados.

Um segundo protótipo claramente menos movimentado mostra Inácio de Azevedo à frente ou ladeado pelos seus companheiros "distinguidos com a coroa do martírio". No caso das pinturas em Tazacorte e Salvador os mártires são representados com alguns dos vários instrumentos usados no seu martírio e ainda com a coroa de santos no caso do quadro em Tazacorte.

Ainda dentro do contexto de iconografias colectivas, à semelhança da decoração do Il Gesù, as galerias de mártires incluem ainda, por vezes, os santos da Companhia e/ou devoções populares entres os jesuítas e episódios bíblicos ${ }^{96}$.

94 Baldinucci, Filippo, Vite de' pittori, scultori, ed architetti moderni, Perugia, Electa Editori Umbri, 1992, p. 215 e Pascoli, Lione, Vite de' pittori, scultori ed architetti moderni, Roma, De Rossi, 1730, pp. 180-181.

95 Richeôme, Louis de, La Peinture Spirituelle ou l'art d'admirer, aimer et louer Dieu en toutes ses oeuvres, et tirer de toutes profit saluter, Lyon, I'imprimerie d'Amy de Polier, 1611, p. 237. (Ver igualmente Bailey, Gauvin Alexander, Between Renaissance and Baroque Jesuit Art in Rome, 1565-1610, Toronto, University of Toronto Press, 2003, pp. 65-66.)

${ }^{96}$ Fondo Schurhammer, Navarra, Schurhammer-III-870 e Schurhammer-III-957. 